\title{
A SZÁMVEVÖSZÉKEK ÉS A CIVIL SZFÉRA KAPCSOLATA AZ ELLENŐRZÉSEK HATÁSOSSÁGÁNAK NÖVELÉSÉRE
}

\author{
Nagy Sándor \\ tanársegéd, Szegedi Tudományegyetem Mérnöki Kar, Szeged
}

SUMMARY

The Supreme Audit Institutions (SAI) have to face several challenges: growing expectations from stakeholders, higher pressure on audit efficiency and in the same time (relative) decreasing financial resources and capacities. The cooperation with civil organizations could generate advantages and more added value of the audit activity. A certain civil organization - owing to its features - could deliver relevant, cheap information and offer available additional professional capacity to the SAI. This promising cooperation has constraints and risks too, which must be managed by the national Supreme Audit Institution. An optimized mixture of the cooperation contribute to the effectiveness of the audit activity.

\section{BEVEZETÉS}

A globális pénzügyi és gazdasági bizonytalanságok, az átrendeződő világgazdasági erőviszonyok és egyéb kedvezőtlen folyamatok következtében egyes kormányzatoknak jelentösen beszükültek a finanszírozási lehetöségei. Ilyen körülmények között egyre nagyobb figyelem és érdeklődés terelödik a közpénzek felhasználásának hatékonyságára mind az országon kívüli mind az országon belüli érintettek körében. A fejlett demokráciákban a civil szféra irányából is markánsan erősödő nyomás nehezedik a hatalomra, hogy szolgáltatásaik nyújtása során, illetve feladatai ellátásához felhasznált közpénzeket minél nagyobb felelősséggel és egyre hatékonyabban költsék el, azaz a közpénzek menedzselése minél magasabb színvonalú legyen. Az említett kívánalmak teljesülésének külső, független ellenörzésére a nemzeti számvevőszékek (Supreme Audit Institution - SAI) jogosultak. Ezek a szervezetek arra hivatottak, hogy kritikus szemmel figyeljék és felügyeljék azokat a kormányzati tevékenységeket, amelyek kapcsán a közszükségletek kielégítéséhez közpénzeket rendelnek az adott feladat ellátásához. A továbbiakban a civil szervezetek és a SAI-k feladatainak összekapcsolódásának lehetőségeiröl lesz szó, melyek fokozhatják a közszféra hatékonyságát és elszámoltathatóságát.

\section{A SZÁMVEVŐSZÉKEK MÜKÖDÉSÉT MEGHATÁROZÓ ÁLTALÁNOS JELLEMZŐK, ÉS AZ ELLENŐRZÉSI FUNKCIÓK HATÁSAINAK NÖVELÉSÉT BEFOLYÁSOLÓ LEHETSÉGES TÉNYEZŐK}

A számvevőszéki tevékenységek rövidtávú eredményeinek és hosszú távú hatásainak érvényesüléséhez, illetve ezek fokozásához számos tényező közrejátszhat. Blume és Voight vizsgálatukban a következő determinisztikus jellemzöket nevezték meg, amelyek érdemben hozzájárulhatnak a teljesítményszint növeléséhez (Blume - Voigt, 2010. p. 4.). Az audit mandátumok lehatárolásához segítségünkre lehet az Ảllami Számvevöszék Ellenörzési Kézikönyve is, amelyben a következő audit típusokat különítik el nemzetközi sztenderdekhez igazodva (ÁSZ 2008. p. 173-174).

(1) A számvevőszék (audit) mandátuma: általánosságban három különböző típusú auditot különböztethetünk meg. (a) Szabályszerüségi ezen belül a pénzügyi-szabályszerüségi ellenörzés (regularity and financial audit): arra keresi a választ, hogy az elszámolások, kimutatások és különösen a költségvetési beszámolók szabályszerüek, törvényesek voltak-e, az adott év beszámolási elveivel volt-e kollízió, és milyen volt a vizsgált szervezetnél, projektnél az év során kialakult financiális helyzet, pénzügyi eredmények illetve a készpénzforgalom. (b) Teljesítmény audit (performance audit, 
value-for-money audit): a számvevő azt ellenőrzi, hogy a közszolgáltatások fogyasztói milyen értéket kaptak a közpénzek felhasználása révén, illetve hatékony, gazdaságos és eredményes volt-e a pénzgazdálkodás. (c) Átfogó ${ }^{9}$ ellenőrzés (comprehensive audit): az auditált szervezet vezetési, szervezési és belsö kontroll mechanizmusait értékeli hasonló megközelítésben, mint a szabályszerüségi audit bár azon túlmutató, komplexebb megközelítésben vizsgálja a feladatok ellátását, megvalósítását, az eröforrások felhasználását és egyéb menedzsment folyamatok kivitelezését.

A számvevöszéki mandátum, felhatalmazás körébe tartozik a közpénzeket érintő döntések utáni (ex post - döntően ez a jellemzö), illetve a döntések előtti véleményezés joga is (ex ante). Az ex ante véleményezés jelentős megtakarításokhoz vezethetnek. A megállapitásokat tartalmazó audit jelentések (audit reports) nyilvánosságra hozatala szintén ebbe a kategóriába sorolható. A nyilvánosság ereje ösztönzöleg hathat a helyes kormányzati viselkedésre. A nem megfelelö közpénzügyi menedzsmentet szankcionáló szerepkör egyértelműen a számvevőszékek mandátumához tartozik.

(2) Számvevöszéki függetlenség: az egyik legmeghatározóbb tényezök egyike. Függetlenség esetén mind a kormányzattól, mind az összes érintettöl érdekeltségben elkülönülten, semlegesen kell végeznie a tevékenységét. A függetlenség szintjének meghatározásához a következőket kell figyelembe venni (Blume - Voigt, 2010. p. 5.) A megfelelő színvonalú ellenőrzéshez rendelkezésre állnak-e a releváns információk, az ellenőrök kinevezésének az időtartama és procedúrája, az ellenőrök javadalmazása, visszahívási lehetősége, a számvevőszék saját költségvetési lehetőségei, gazdálkodásának határai, a függetlenséget garantáló alkotmányos garanciák.

(3) A számvevőszék szervezeti, társadalmi-gazdasági környezete: ha nincs felhatalmazása szankcionálásra, akkor mindenképp szükség van egy független bíróságra, hogy érvényesülhessenek a SAI megállapításai és kihatással legyenek a közpénzek kezelésére. Egyes országokban megjelentek ugyanakkor a számvevőszékek tevékenységeit kiegészítő szervezetek, intézmények, mint például az ombudsman vagy a korrupcióellenes ügynökségek. A számvevőszékek megállapításainak közvetítésében és a társadalom széles köreiben is érthetövé tételében egyre inkább szerepet vállalnak a civil szervezetek is. A számvevőszékek és a civil szervezetek szorosabb együttmüködésének okaival a további fejezetek foglalkoznak (Blume - Voigt, 2010. p. 5.)

Annak ellenére, hogy a számvevőszéket tevékenységének hatásosságáról számos tanulmány beszámol, vannak olyan szerzök, akik kritikusan kezelik ezeket az eredményeket, és anomáliảkat azonositanak müködésükkel kapcsolatosan. Frey arra hívja fel a figyelmet, hogy a számvevőszékek alkalmazottai szintén bürokraták, és figyelmen kívül hagyják a nem pénzügyi jellegü költségeket az ellenőrzések során, valamint túlzó részletességgel tárnak fel apróbb eltéréseket, miközben a jelentős hiányosságokról nem készül jelentés (Frey 1994). Blankart még ennél is továbbmegy. Véleménye szerint nincs vétójoga a szervezetnek, hogy kiadásokat visszatartson, kívülállóként nehezen tud bizonyítani bármilyen hiányosságot, míg tagjai nem rendelkeznek bírói jogkörrel, továbbá a számvevőszékek monopolhelyzetben vannak tevékenységüket illetöen, ami nem helyez rájuk kompetitív nyomást, és végezetül jelentéseik, észrevételeik a régmúltra utalnak vissza, amely már nem nagyon érdekli a közvéleményt (Blankart 2006) ${ }^{10}$.

\footnotetext{
${ }^{9} \mathrm{Az}$,átfogó" elnevezés nem adja jól vissza a fogalom tartalmát, az angol kifejezés nehezen fordítható le.

${ }^{10}$ A megfogalmazott kritikák inkább túlzó véleményeket tartalmaznak, mintsem érdemben ragadnák meg a külsö, független ellenõrzés esszenciájảt.
} 


\section{A SZÁMVEVÖSZÉKEK ÉS A CIVIL SZERVEZETEK EGYÜTTMỦKÖDÉSÉNEK MOTIVÁCIÓI}

$\mathrm{Az}$ említett vélemények ellenére a számvevöszékek léte, funkciói elengedhetetlenek a társadalom, az állam és a gazdaság számára is. De vajon miért kap egyre nagyobb szerepet a külsö ellenörzés és a civil szervezetek összefogása? Milyen motivációs erök vezetik a két felet, hogy együttmüködjenek? A kérdések megválaszolásához elöször is szükséges a civil szektor, az állam és a SAI közötti kapcsolatok leegyszerüsített - a téma szempontjából fontos szempont szerinti - ábrázolása. Az ábra két szektort jelenít meg a köztük lévő információ- és pénzáramlással együtt, valamint a független számvevöszéket, amely funkciói révén információkat gyüjt össze, majd tematikus szempontok szerint feldolgozva azokat továbbitja az érintettjei (stakeholderei) részére (transzformációs hatás). A rendezett információtömeg (audit jelentések, publikációk, tanulmányok stb.) áramolhat az állam felé, amely visszacsatolásként szolgál a közpénzügyi menedzsmentre vonatkozóan, illetve áramolhat a civil szféra irányába, ahol a publicitás révén felerösödhetnek a megállapítások hatásai. A minél szélesebb körü, érthetőbb tájékoztatás növelheti a bizalmat a kormányzati gazdálkodás irányában. A determinisztikus környezet olyan dinamikusan változó lehatárolás, amelyben a szereplök, aktorok döntései, tevékenységei érdemben kihatnak a számvevőszékre, annak szervezeti tulajdonságaira, felhatalmazásaira (mandátum), ellenörzési és egyéb kapcsolódó tevékenységeire.

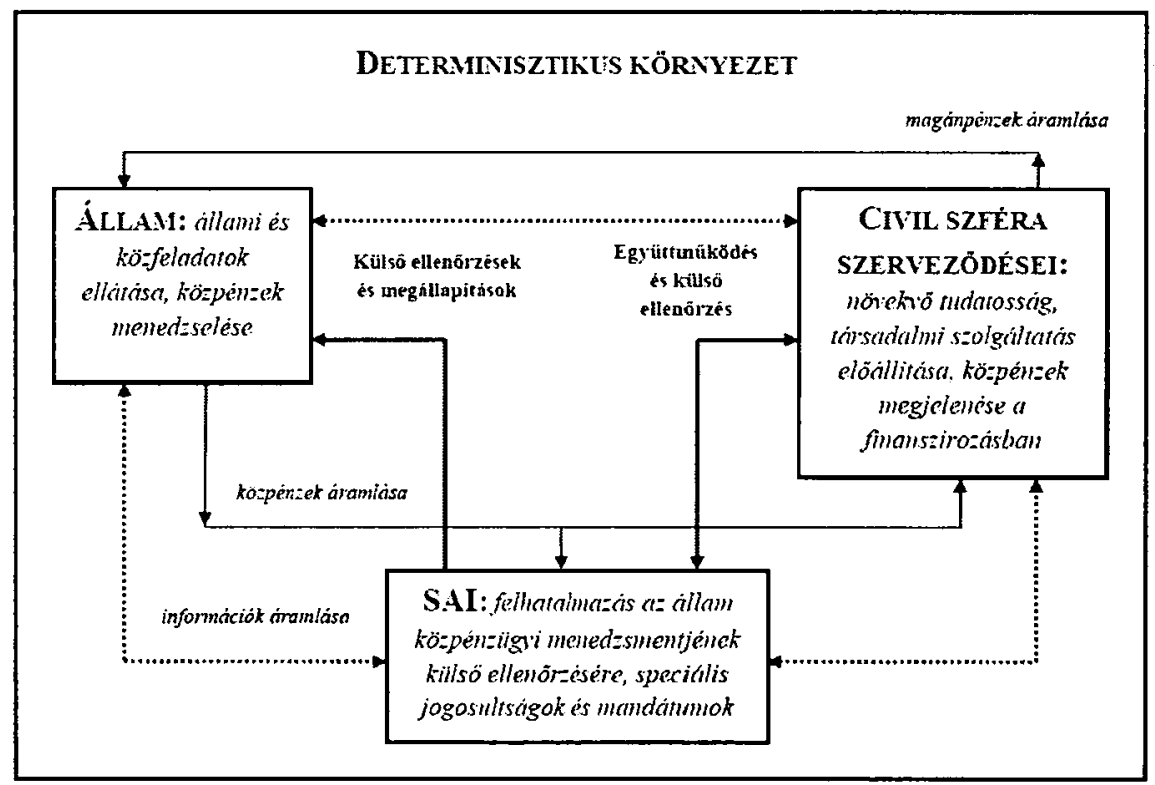

1. ábra: Az állam, a civil szféra és a SAI közötti pénz- és információáramlások Forrás: felhasznált irodalmak alapján saját szerkesztés

A nonprofit vagy más néven harmadik szektort alkotó civil szervezetek mint az állampolgárok önkéntes alapon történő szervezödései a társadalom fontos építőelemeit jelentik, és funkcióik révén jelentös szerepet töltenek be a területi folyamatok alakításában (Kis - Kocsis-Nagy, 2010). A civil szervezetek a társadalom azon csoportjai, amelyek különböző célok mentén szerveződő nem kormányzati szervezetek, és hatékonyan tudnak bizonyos helyi közösségi érdekeket képviselni, ugyanakkor specializációjuk, jellegzetességeik révén olyan információk, tapasztalatok, tudás birtokában vannak, amelyek a számvevőszék hatásos ellenőrzése 
szempontjából fontosak lehetnek, éppen emiatt kiemelt fontossággal kell kezelni a számvevőszékeknek ezeket a csoportosulásokat. A módosított meghatározás eredetije Bajmócy nevéhez füződik (Bajmócy 2011. p. 106). A téma szempontjából egzaktabb megközelítést Kovács Árpád adja meg: a nonprofit szektor elemei (egyesületek, alapítványok, szövetségek, közhasznú társaságok, egyéb társadalmi szervezetek, civil szerveződések) jelentös közösségi forrásokat használnak fel, ugyanakkor a közpolitika formálóiként, változásgeneráló organizációkként azonosíthatóak és potenciális kihatásuk van a közkiadások alakítására. Közös jellemzöjük, hogy közfeladatuk ellátása kapcsán föleg társadalmi szolgáltatásokat nyújtanak, amelyek pártok ${ }^{11}$, egyházak, szakszervezetek, kamarák esetében igen speciális: ekkor közösségszervezö, együttmüködésre serkentő szellemi „szolgáltatásokról"van szó (Kovács 2010 p. 320-329).

Az együttmüködés elönyei a SAI szemszögéböl: (Pyun 2006; Ramkumar 2007a,b; INTOSAI 2011):

- A SAI-k és a civil szervezetek együttmüködése elösegíti a gazdasági fejlődést, a fenntartható fejlödést, a szolgáltatások nyújtását és a korrupció elleni küzdelmet

- a társadalom tagjai, illetve a belölük szerveződő civil organizációk a kormányzati szolgáltatások, tevékenységek végfogyasztóiként olyan ismeretek birtokában vannak, amelyek a kormányzati teljesítmény megítélésekor hasznosnak bizonyulhatnak

- A társadalommal és a civil szervezetekkel folytatott információcsere növelheti a számvevőszékek elismertségét és a közszféra iránti bizalmat

- A hatékony kommunikáció és a releváns információk megosztása növelheti a társadalom tagjainak a tudatosságát, figyelmét a közügyek és a közszolgáltatások minősége iránt

- A hibákról és a lehetséges kockázatokról szóló számvevőszéki jelentések lehetővé teszi a társadalom tagjai számára, hogy döntéseiket hiteles információkra alapozva tudják meghozni, így a SAI legfontosabb érintettjeinek nyújtott érték növekszik

- A civil szervezetek - mint a társadalomi elvárásokat speciális dimenziók mentén kikristályosító, tömöritő szervezet - igényeinek a beépítése az ellenőrzési stratégiákba, illetve a tevékenységi és ellenörzési tervekbe tovább emeli az ellenőrzési megállapítások hitelességi szintjét

- A civil szervezetek „lefordítják” a jelentések szakmai nyelvezetét és közérthetővé teszik a szélesebb közönség számára is, amely növelhetik az audit tevékenység impaktját

- A civil szervezetek önkéntes, saját funkcióikhoz kapcsolódó, elkötelezett vizsgálódásai kiegészíthetik a számvevőszékek munkáját

- A szükösen rendelkezésre álló erőforrások miatt (anyagi lehetőségek, kapacitáshiány stb.) a külső auditor szervezetnek szüksége lehet könnyen hozzáférhető, releváns információkra, illetve a civil szervezetek szakemberei külső szakértöként is tevékenykedhetnek olykor bármiféle anyagi ellentételezés nélkül

- A különféle társadalmi, gazdasági területekben érintett civil szervezetekkel kiépített információs hálózat diverzitása, heterogenitása elösegítheti az ellenörzési tevékenységgel kapcsolatos tudás vagy innováció kialakulását

- Nem elfelejtendő, hogy az együttmúködésben résztvevö civil szervezet számára is számos előnyt jelent a SAI jelenléte: egyéni szervezeti célok valószínübb

\footnotetext{
"A pártok gazdálkodásának szabályszerüségi ellenörzése - egyedullálló módon - Magyarországon az Állami Számvevöszék feladata. Lásd részletesebben: 1989. évi XXXIII. törvény - a pártok müködéséröl és gazdálkodásáról, illetve 2011. évi LXVI. tơrvẻny - az Állami Számvevöszékröl.
} 
teljesülése, nyomatékosabb fellépés, szakmai fejlődés, ellenörzéssel kapcsolatos információkhoz való könnyebb hozzáférés (Ramkumar 2007b)

Természetesen a potenciális együttmüködés kockázatokat és hátrányokat is hordozhat magában (Pyun 2006; Ramkumar 2007a,b; NTOSAI 2011):

- a túl sok civil szervezettel kialakitott szorosabb együttmüködés megoszthatja a számvevöszékek amúgy is szükös eröforrásait, csorbul az ellenörzési munka hatékonysága

- Nemzetbiztonsági szempontból érintett ellenőrzésekkor aggályos lehet egy civil szervezet jelenléte, beavatkozása

- A civil szervezetek és a számvevőszékek kooperáciọja során elképzelhető, hogy a különbözö alkalmazott ellenörzési módszerek, illetve az eltérö szakmai hátterek miatt a tevékenység összehangolása további kapacitások kiépítését követeli

- Az együttmüködés rossz fényben tüntetheti fel a számvevöszékek egyik legfontosabb deklarált jellemzöjét a függetlenséget, illetve az együttmüködésre kiválasztott civil szervezet esetleges hozzá nem értése árnyékot vet a SAI magas szintü szakmai profizmusára

\section{AZ INTOSAI VÉLEMÉNYE ÉS AJÁNLÁSAI A CIVIL SZFÉRÁVAL VALÓ EGYÜTTMÜKÖDÉSRŐL}

A fentebb leírt elönyök és hátrányok ismeretében az INTOSAI - International Organization of Supreme Audit Institutions - a legföbb ellenörzö intézmények nemzetközi szakmai szervezete, amelynek az egyik legfontosabb feladata, hogy a tagintézményeknek szakmai útmutatásokat adjon, a következỏ ajánlásokat teszi a nemzeti számvevőszékek számára. A javaslatok összhangban állnak a Limai és Mexikói Nyilatkozatokkal (INTOSAI Deklarációk), amelyek különös hangsúlyt fektetnek az audit megállapítások relevanciájára, közérthetőségére, minden egyes érintett számára könnyü elérhetőség biztosítására, továbbá arra, hogy az eredményeket a legújabb, leghatékonyabb csatornákon keresztül közvetítsék a társadalom tagjai részére (INTOSAI 2011.p. 4).

A nemzeti számvevöszékeknek a hosszú távú hatásaiknak növelésére, a tevékenységük hozzáadott értékének megteremtéséhez ajánlott, hogy jó kapcsolatokat alakítsanak ki az érintettekkel, ezen belül a civil szervezetekkel is, és az ezekre vonatkozó elképzeléseket építsék be a PR és kommunikációs stratégiákba is. Az együttmüködés lehet mélyebb is, hiszen részvételükkel könnyebben feltárhatóak a társadalmi kifogások és a közpénzek hibás felhasználảsa, valamint olyan javaslatok, amelyek a közszolgáltatások színvonalának emelésére hivatottak. Az kooperáció során a számvevőszékeknek olyan mechanizmusokat kell kiépíteniük, amelyek segítik a társadalmi visszacsatolások érzékelését és kiértékelési lehetőségét. A SAI-knak fel kell térképezniük a civil szervezetek részvételét, befolyását, hozzájárulását a költségvetési folyamatokat illetően, hiszen maga a büdzsé képezi az ellenörzés alapját. A tudományos és kutatóintézetekkel való célirányos együttmüködés kialakítása hozzájárulhat a lakosság növekvő tudatosságához és érzékenységére az elszámoltathatóságot illetỏen. Az ajánlások terjesztéséhez, a gyakorlati alkalmazások elösegítéséhez az INTOSAI egy szakmai útmutatót (Guidance) dolgoz ki, amely olyan elemeket, feltételeket, kondiciókat tartalmaz, amik reagálva a lehetöségekre és a valós kockázatokra hozzájárulnak a tagintézmények hatásosabb müködéséhez. Sikeres együttmüködések elemzését találhatjuk Ramkumar átfogó tanulmányában, amely rámutat a számvevöszékek és a civil szervezetek kooperációjának mindkét oldalára (Ramkumar 2007b). 


\section{ZÁRÓ GONDOLATOK}

A számvevöszékek szorongatott helyzetben vannak: egyre több elvárásnak kell megfelelniük, miközben szükülö eröforrásokkal kell szembesülniük. Az INTOSAI javaslatainak megfogalmazásakor számos kérdéskört azonban tisztázatlanul hagyott, amelyeknek a pontosítását a nemzeti számvevőszékekre hagyják. A kényes egyensúly megteremtése a deklarált függetlenség és az optimalizált számú és mélységü együttmüködések, a közös audit tevékenységek, a külső szakértői segítségnyújtás és az információ áramoltatás, transzformálás között így továbbra is a helyi környezethez leginkább igazodni tudó nemzeti számvevőszéki menedzsment feladata marad. A civil szervezetekkel való együttműködés elősegítheti a hatékony és eredményes audit tevékenység megvalósulását, hiszen minőségi, releváns és olcsón beszerezhető információkhoz juthat a SAI, miközben szakértői kapacitással is bövülhetnek a felhasználható inputok köre. A számvevöszékek egyre nagyobb részénél figyelhető meg a civil szféra felöl érkezö jelzések, észrevételek tudatos befogadása, amelyek akár vizsgálat-generáló, súlypontozó tényezők is lehetnek. A fentebb leírt folyamatban kitüntetett szerephez kellene jutniuk a harmadik szektor azon szervezödéseinek, amelyek nyomatékos érdekérvényesitő és szakmai értékformáló erövel bírnak, és hozzá tudnak járulni az ellenörzési tapasztalatok, javaslatok adaptálásához, átviteléhez. Mindezekkel párhuzamosan a kimeneteli (output) oldalon, az audit tevékenység hatásának, a hozzáadott értékének növelésében szintén tud érvényesülni a kooperáció.

\section{IRODALOMJEGYZÉK}

Állami Számvevőszék (2008): Az Állami Számvevőszék Ellenőrzési Kézikönyve - A számvevőszéki ellenőrzés szakmai szabályai. ÁSZ Módszertani Kiadványok Második tartalmilag korszerüsített kiadás.

http://www.asz.hu/ellenorzes-szakmai-szabalyok/ellenorzesi-kezikonyv

Bajmócy, Z. (2011): Bevezetés a helyi gazdaságfejlesztésbe. JATEPress Szeged, 2011.

Blankart, C.B. (2006): Öffentliche Finanzen in der Demokratie: Eine Einführung in die Finanzwissenschaft. 6. völlig überarbeitete Auflage. Verlag Franz Vahlen, München.

Blume, L. - Voigt, S. (2010): Does organizational design of supreme audit institutions matter? A cross-country assessment. In: European Journal of Political Economy (2010), doi:10.1016/j.ejpoleco.2010.07.001

Frey, B.S. (1994): Supreme auditing institutions: a politico-economic analysis. In: European Journal of Law and Economics. 1, 169-176.

INTOSAI (2011): Conclusions and recommendations of the 21 st UN/INTOSAI Symposium on effective practices of cooperation between supreme audit institutions and citizens to enhance public accountability. Vienna, Austria 2011.

http://www.intosai.org/blueline/upload/18conclusions20071le.pdf

Kis, K. - Kocsis-Nagy, Zs. (2010): Civil aktivitás és társadalmi részvétel. A Hódmezővásárhelyi kistérség nonprofit szektorának vizsgálata megyei, regionális és országos kitekintéssel. Területi statisztika. 5. 530-550.

Kovács, Á. (2010): Közpénzügyek. ELTE Eötvös Kiadó, Eötvös Loránd Tudományegyetem Budapest, 2010.

Pyun, H. (2006): Audit and Civil Society: The Korean Experience. In: International Journal of Government Auditing, Technical Articles, INTOSAI.

Elektronikus elérhetőség: http://www.intosaijournal.org/technicalarticles/technicalapr06.html

Ramkumar, V. (2007a): Expanding Collaboration between SAIs and Civil Society. In: International Journal of Government Auditing, Technical Articles, INTOSAI.

Elektronikus elérhetőség: http://intosaijournal.org/technicalarticles/technicalapr2007a.html 
Ramkumar, V. (2007b): Our Money, Our Responsibility - A Citizens' Guide to Monitoring Government Expenditures. The International Budget Project. Washington D. C., USA. http://www.sasanet.org/curriculum_final/downlaods/PM/Working\%20Papers $\% 20 \& \% 20$ Case $\% 20$ Studies $/ 03 \% 20$ Expenditure $\% 20$ Monitoring\%20Guide $\% 20$ -

$\% 20$ Vivek\%20Ramkumar\%20Procurement.pdf 